\title{
The Anti-Enlightenment Tradition as a Common Framework of Fascism and the Contemporary Far Right
}

\author{
Tamas Dezso Ziegler \\ Institute of Political and International Studies, Eötvös Loránd University, \\ Budapest, Hungary \\ ziegler.tamas@tatk.elte.hu
}

\begin{abstract}
The relationship between far-right political streams and fascism is a recurring topic in scientific literature. However, we find a low number of academic publications which try to create a framework for their similarities. This article uses Zeev Sternhell's theory of fascism as a tool to measure different interpretations of fascism and the far right. According to its basic statement, there exists an anti-Enlightenment tradition in the Western world, which could serve as a substratum of these streams. This proves two points. Firstly, that there are several political groups which share a very similar political vision, even if their levels of aggression and radicalism are different. This is the reason why many neo-fascist, post-fascist, 'populist' and conservative parties have interchangeable rhetorical clichés and ideological patterns. Second, it shows that Western countries could successfully fight the rise of upcoming anti-democratic forces through strengthening the values of the Enlightenment-tradition.
\end{abstract}

\section{Keywords}

far right - post-fascism - neo-fascism - anti-Enlightenment tradition - Zeev Sternhell $\left(1935^{-2020)}\right.$

\section{The Concept of Fascism and the Renewed Fascism Debate}

Recently, once again, in public debates, politicians and intellectuals belonging to the far right are regularly being labelled as 'fascists'. To mention only a few 
such incidents, regarding Trump's election, Robert Kagan, a notable scholar of international relations, wrote an article for the Washington Post telling us that 'this is how fascism comes to America.' Timothy Snyder from Yale University compared fascism with Putin's foreign policy, ${ }^{2}$ warning us that 'post-truth is pre-fascism, ${ }^{3}$ and wrote a guidebook for the everyday citizen on how to fight against state oppression. ${ }^{4}$ Even former US Secretary of State Madeleine Albright published a book on the dangers of fascism in the US. ${ }^{5}$ On the other hand, most of the mainstream scholarly community seems to be reluctant to use the term 'fascism' for far right (or, in its interpretation, 'populist') politicians. For example, regarding Trump, Robert Paxton from Columbia University says that if he could make his believers wear a uniform (like the black shirt of Italian fascists) and force them to provoke aggression, fights or assassinations, he would consider Trump to be a fascist, but this is not the case. ${ }^{6}$ According to Paxton, even though Trump uses fascist-like rhetoric, exploits racial prejudices and tries to represent force, he is not a fascist: what we can see is the rise of a businessman who believes that ideas such as inciting xenophobia could be more beneficial for him than explaining the details of tax reforms or other regulatory questions. Trump's motivation is his self-interest. ${ }^{7}$ A similar opinion is reflected in Roger Griffin's short article about Trump. As he put it,

I grant that 'Trump Is a Radical Right-Wing Populist' has less of a (populist) ring as a headline than 'Trump Is a Fascist' and lends itself to less funny cartoons, but that is what he is. He wants America to be great again, but not to be reborn in a totalitarian new order, let alone force its

Robert Kagan, 'This is how Fascism comes to America,' The Washington Post, May 18, 2016. 'Fascistic? Russia's Foreign Policy in the Putin Era,' Democracy Digest, May 2o, 2016, http:// www.demdigest.org/fascistic-russias-foreign-policy-putin-era/; Timothy Snyder, 'Trump's Putin Fantasy,' New York Review of Books, April 19, 2016, http://www.nybooks.com/ daily/2016/04/19/trumps-putin-fantasy/.

'Post-Truth is Pre-Fascism: A Holocaust Historian on the Trump Era,' Vox, March 9, 2017, https://www.vox.com/conversations/2017/3/9/14838088/donald-trump-fascismeurope-history-totalitarianism-post-truth. Timothy Snyder, On Tyranny: Twenty Lessons from the Twentieth Century (New York: Tim Duggan Books, 2017).

$6 \quad$ Fedja Buric, 'Father of Fascism Studies: Donald Trump Shows Alarming Willingness to Use Fascist Terms \& Styles,' Democracy Now! March 15, 2016, https://www.democracynow. org/2016/3/15/father_of_fascism_studies_donald_trump.

7 Isaac Chotiner, 'Does Donald Trump Believe in Anything but Himself? The Republican Candidate's Fascist Impulses are Frequently Rooted in his Own Self-Interest,' Slate, October 24, 2016, http://www.slate.com/articles/news_and_politics/interrogation/2016/10/ donald_trump_s_fascism_is_rooted_in_his_own_self_interest.html. 
citizens to be subjected to a coercive state monopoly of power, which for one thing would stop billionaires like him from enjoying the fruits of their ill-gotten gains or running for president. ${ }^{8}$

This ambivalence around the term 'fascism' has been present for decades, probably since Gilbert Allardyce joined those who would ban everyone from using it, ${ }^{9}$ or maybe even earlier, when in the 1920 Leon Trotsky refused to use the term 'fascism' to denounce certain conservative political parties. Even regarding hundred-year-old political streams, this was present: see, for example, the case of Nolte and the problem of the proto-fascism of Charles Maurras, ${ }^{10}$ or the ambiguity around para-fascist leaders like the Hungarian Gyula Gömbös ('Gömbölini', as he was referred to by the public). In itself, the debate is uninteresting, even if the old consensus on fascism seems to disappear or change."1 What is more interesting is what the root cause of such disputes could be. Why are there fundamentally different views by notable scholars about fascist-like rhetoric, ${ }^{12}$ neo-fascism and post-fascism? Explaining it as ignorance is false and a rather elitist view, in this author's opinion, as there are many great scholars who interpret the term 'fascism' more broadly than mainstream academia.

Nigel Copsey addressed this problem in the Oxford Handbook of the Radical Right. As he put it,

[t]he point that needs to be made is that (neo)fascism shades into radical right populism: they are not identical, but neither are they so 'essentially' or 'utterly' different that imposing a break on the historical lines of continuity between 'classic' fascism and the contemporary radical right is justified. That this chapter, which reinstates the link between the radical right and fascism, should appear in a volume devoted to the radical right might prompt political scientists (and some historians) to rethink their views on the thorny relationship between fascism and radical-right

8 Roger Griffin, 'The Last Trump?' September 8, 2016, https://divinity.uchicago.edu/ sightings/articles/last-trump.

9 Gilbert Allardyce, 'What Fascism is Not: Thoughts on the Deflation of a Concept,' The American Historical Review 84, no. 2 (1979): 367-388.

Ernst Nolte, A fasizmus korszaka [Three Faces of Fascism] (Budapest: Kairosz, 2003), 65-420.

Roger Griffin, 'Studying Fascism in a Postfascist Age: From New Consensus to New Wave?' Fascism 1, no. 1 (2012): 1-17, https://doi.org/10.1163/221162512X623601; Ruth Wodak and John E. Richardson, ed., Analysing Fascist Discourse: European Fascism in Talk and Text (New York [etc.]: Routledge, 2013). 
populism. At the very least, I hope to open up a more productive dialogue where this question is considered worthy of far more serious debate and is not so freely dismissed. ${ }^{13}$

The aim of this article is to present one answer to Copsey's claim, trying to create a kind of common framework for the different political streams. As a follow-up to Zeev Sternhell's ideas on fascism, it claims that fascism, contemporary far right and so-called 'populist' political forces share many anti-Enlightenment ideas, and it is not a coincidence that similar political ideas return in history.

\section{The (Anti-)Enlightenment Tradition as a Historical Value System}

When talking about the connection between the far right and historical fascism, one can hardly fail to notice that several political patterns that exist today in our European societies were already present at the dawn of the twentieth century. The idea of a 'cultural decadence' has gotten stronger, according to which Europe and its countries are in danger and heading towards disaster because of self-destructive liberalism and democracy, rule of law, human rights, and checks and balances. There is a political will to try to transform nations into reactionary tribal cultures; ${ }^{14}$ some claim that multinational boundaries offend state interest, and search for enemies within and outside their countries. It is also stated that multiculturalism leads to the loss of cultural identity and intellectual nihilism. International migration ${ }^{15}$ had strengthened racist and xenophobic attitudes: more than 23,000 crimes were committed by the far right in Germany in 2017, about 9oo asylum homes were attacked, 1,313 cases of physical assault resulted in injury, and there were 18 attempted murders. ${ }^{16}$ Social Darwinism returns in new forms, and many accept that it is weak nations'

13 Nigel Copsey, 'The Radical Right and Fascism,' in The Oxford Handbook of the Radical Right, ed. Jens Rydgren (Oxford: Oxford University Press, 2018), 17.

Robert J. Antonio, 'After Postmodernism: Reactionary Tribalism,' American Journal of Sociology 106, no. 1 (2000): 40-87.

15 Jürgen Basedow, The Law of Open Societies: Private Ordering and Public Regulation of International Relations (Leiden-Boston: Brill Nijhoff, 2013), 59 et seq.

16 'Germany: Far-Right Violence and Islamist Threat on the Rise,' Deutsche Welle, July 4, 2017, https:/www.dw.com/en/germany-far-right-violence-and-islamist-threat-on-therise/a-39534868; 'More Murder and Violence in Germany,' Deutsche Welle, April 24, 2017, https://www.dw.com/en/more-murder-and-violence-in-germany/a-38567642; David Crossland, 'How Germany Combats Far-Right Extremism,' Handelsblatt, August 16, 2017, https://www.handelsblatt.com/english/politics/handelsblatt-explains-how-germanycombats-far-right-extremism/23571764.html. 
destiny to fail. A kind of 'macho cult' also reappears, attacking feminism and gender studies. ${ }^{17}$ Part of the Western population is dissatisfied with its living standards, and the gap between the rich and the poor is increasing: some commentators claim this is one important factor behind the rise of the far right, ${ }^{18}$ while others also talk about the return of materialist values and a cultural backlash. ${ }^{19}$ Propaganda in certain countries, conspiracy theories and 'fake news' have become widespread, and politics has seemingly drawn closer to quasi-religious belief systems. The scapegoating of minorities and conspiracy theories have also become common. The nation as an organic decision-making actor has appeared again: instead of the individual and the community, blood relations to the nation receive priority in the political rhetoric of certain groups. People who have different perspectives are excluded, discriminated against and threatened, being told that their political affiliation, religion, gender or ethnic background does not adhere to the nation's principles. ${ }^{20}$ There is no democratic consensus on the rules of democracy, described by Alfred C. Stepan and Juan Linz as the 'only game in the city': ${ }^{21}$ certain groups 'play different games', and want to boost their power even against the rule of law. In certain electoral autocracies like Russia and Hungary, the political system is centralized around the leading party (hegemonic party system, meaning there is no real competition among parties).

On the other hand, one could argue that the contemporary far right is not as destructive as historical fascism, even if the role of aggression against minorities in fascism was not as univocal as it sometimes seems, especially in Mussolini's Italy. ${ }^{22}$ One could also add that in some countries, so-called 'populist' parties became members of governments and they did not abolish checks

European University Association, 'EUA Condemns Hungarian Government Plan to Ban Gender Studies,' August 24, 2018, https://eua.eu/news/13o:eua-condemns-hungariangovernment-plan-to-ban-gender-studies.html.

Agust Arnorssona and Gylfi Zoega, 'On the Causes of Brexit,' European Journal of Political Economy 55 (2018): 301-323, https://doi.org/10.1016/j.ejpoleco.2018.o2.0o1.

Ronald F. Inglehart and Pippa Norris, 'Trump, Brexit, and the Rise of Populism: Economic Have-Nots and Cultural Backlash,' HKS Faculty Research Working Paper Series, RWP16-026, August 2016, https://www.hks.harvard.edu/publications/ trump-brexit-and-rise-populism-economic-have-nots-and-cultural-backlash.

Ákos Kopper, Balázs Majtényi and Pál Susánszky, 'Constitutional Othering, Ambiguity and Subjective Risks of Mobilization in Hungary: Examples from the Migration Crisis,' Democratization 22, no. 5 (2018): 7 . Juan J. Linz, and Alfred Stepan, Problems of Democratic Transition and Consolidation (Baltimore: Johns Hopkins University Press, 1996), 5. See the disputes surrounding De Felice and his statement that Italian Fascism was not inherently racist. See also Joshua D. Zimmerman, ed., Jews in Italy Under Fascist and Nazi Rule, 1922-1945 (New York: Cambridge University Press, 2009); Aaron Gillette, Racial Theories in Fascist Italy (London: Routledge, 2002). 
and balances and multi-party systems altogether; and, as mentioned before, in the United States, after the election of Donald Trump, the political framework was not changed drastically either. The reason for the similarities is that Zeev Sternhell was right when he wrote that

while the eighteenth century is commonly perceived as the quintessential age of rationalist modernity, it was also the cradle of a second and strikingly different modernity. In fact, at the very moment when rationalist thought seemed to have reached its peak, a comprehensive revolt against the Enlightenment's fundamental views erupted in European intellectual life ... It was very soon apparent ... that the cultural victory of rationalism was eliciting a violent response... In 1725 Giambattista Vico produced the first version of his Scienza nuova (New Science), which from our perspective was the first link in the chain of antirationalism and anti-intellectualism, of the cult of the particular and the rejection of the universal. ${ }^{23}$

While in Sternhell's opinion, fascism is a kind of ultranationalist form of socialism, as such it is also an anti-enlightened cultural phenomenon, containing many of the elements mentioned above. Please note that this take is basically different from the interpretation of many scholars, who claim that fascism was an offspring of the Enlightenment, either because the Enlightenment was oppressive, ${ }^{24}$ or because fascism was based on a certain kind of enlightened rationale. ${ }^{25}$ When Sternhell proved that antisemitic exclusion and authoritarianism (a kind of 'home-grown fascism') was present among French conservative

Zeev Sternhell, The Anti-Enlightenment Tradition (New Haven: Yale University Press, 2010), I.

Reinhart Kosseleck, Critique and Crisis: The Enlightenment and the Pathogenesis of Modern Society (Cambridge: MIT Press, 1988); cf. Franz Leander Fillafer, 'The Enlightenment on Trial: Kosseleck's Interpretation of Aufklärung,' in The Many Faces of Clio: Cross-Cultural Approaches to Historiography, ed. Franz Leander Fillafer and Edward Q. Wang (New York, Oxford: Berghahn, 2007), 322-345.

Isaiah Berlin, Freedom and Its Betrayal (Princeton: Princeton University Press, 2003); Isaiah Berlin, 'The Counter-Enlightenment,' in Against the Current: Essays in the History of Ideas (New York: Pimlico, 1979), 1-35; William A. Galston, 'Moral Pluralism and Liberal Democracy: Isaiah Berlin's Heterodox Liberalism,' The Review of Politics 71, no. 1 (2009): 92; Theodor Adorno and Max Horkheimer, Dialectic of Enlightenment (Stanford: Stanford University Press, 2002); Michael Arthur Ledeen, 'Introduction,' in Fascism: An Informal Introduction to Its Theory and Practice, ed. Renzo De Felice (London: Taylor and Francis, 1976), 15; Stanley G. Payne, 'Historical Fascism and the Radical Right,' Journal of Contemporary History 35, no. 1 (2000): 111. 
intellectuals and in certain clubs, ${ }^{26}$ it was not l'art pour l'art science: this very important finding was to show how fascist and conservative groups with certain common ideas can intermingle and develop. The same happened in Italy, where black shirts were supported by blue shirt conservatives at the birth of fascism. In Sternhell's interpretation,

the Enlightenment was not a consistent theoretical structure but rather an intellectual tradition with immediate and practical objectives. Yet, despite the many differences between Voltaire on the one hand and Rousseau on the other, Rousseau on the one hand and Jean-Antoine-Nicolas de Caritat de Condorcet on the other, Charles-Louis de Secondat de Montesquieu on the one hand and Diderot and the encyclopédistes on the other, the thinkers of the French Enlightenment and their principal ally, Kant, had certain principles in common that constituted the very heart of the eighteenth-century intellectual revolution. ${ }^{27}$

This intellectual tradition today contains belief in the individual, with his/ her human rights not merely granted but protected by the state. It contains universalism, 'freedom, individual autonomy, and toleration'.28 In its present, developed form, this tradition also contains political and intellectual pluralism, and the tolerance of different political views (as long as they do not pose a danger to the democratic system, as Popper stated ${ }^{29}$ ). It secured people the right to decide about their own governance, and handled people (man-woman, rich-poor, black-white, religious people-atheists) equally. It separated church and governance, pushed the church out of politics and into the private sphere. It also created checks and balances of governance, because it realized that power can be destructive. Based on this interpretation, terror, including the Jacobin terror, is not part of the Enlightenment tradition, as terror goes against its fundamental principles. Payne and Mosse mention that the Jacobin terror also derives from the Enlightenment, ${ }^{30}$ and many commentators follow this

26 Zeev Sternhell, Neither Right nor Left: Fascist Ideology in France (Princeton: Princeton University Press. 1995).

27 Zeev Sternhell, The Anti-Enlightenment Tradition (New Haven: Yale University Press, 2010), 4 .

28 Ibid.

29 'We should therefore claim, in the name of tolerance, the right not to tolerate the intolerant. We should claim that any movement preaching intolerance places itself outside the law...' Karl Popper, The Open Society and Its Enemies, Vol I. (London: Routledge, 1947), 226.

30 Stanley G. Payne, 'Review Article: Historical Fascism and the Radical Right,' Journal of Contemporary History 35, no. 1 (2000): 111. 
argument regarding totalitarianism. They mention violent and authoritarian tactics, unified mass mobilization, secular civic religion, the emphasis on symbolic action, a kind of 'political festival', the fascination of death and youth, the strong leadership and the newspeak as all deriving from the French Revolution. On the other hand, looking back more than two hundred years later, one can surely say that terror obviously goes against the humanistic tradition of the Enlightenment i.e. certain core principles set up by most of the thinkers of the Enlightenment. This tradition was even strengthened and more defined in the course of history. Oppression, and the government structure necessary to use it, can be interpreted as the 'shadow' of the Enlightenment tradition, which was born at the same time as tolerance and secular rationality. This shadow was turned into a system in the Jacobin terror and later in the fascist regimes. This means that there is another old tradition, which goes against the principles of the Enlightenment. The Enlightenment tradition maintains that democracy is not the same as state terror supported by the society. Even if Mussolini wrote about some kind of 'authoritarian democracy' in the Enciclopedia Italiana, ${ }^{31}$ any form of government oppression is against this tradition, as it goes against individualism, humanism (human rights) and human dignity. The same is true regarding our thinking about the nation. Most Enlightenment authors used a national framework: however, when human rights and rational decision-making are destroyed by an aggressive nationalistic myth, this national myth greatly oversteps the boundaries accepted by most Enlightenment thinkers, and by the tradition which developed later based on their ideas. The same is true of rationality: claims that the Nazi system was based on a certain kind of rationality rooted in the Enlightenment are mistaken: there is nothing rational in a state which kills millions of people, and where even economics were far weaker, more corrupt and more vulnerable than is sometimes portrayed. ${ }^{32}$

'Fascism may write itself down as "an organized, centralized, authoritative [i.e. authoritarian] democracy"' Benito Mussolini and Giovanni Gentile, The Doctrine Of Fascism (London: Hogarth Press, 1933), 16. - Doing Business Under Fascism (New York: 1939, new imprint by Mises Institute, 2007), 217. As Christopher Duggan put it regarding Italy, '[d] espite the regime's claims to be forging new men and women and ridding the country of the vices that had bedevilled liberal Italy, corruption and clientelism proliferated on what appears to have been an unprecedented scale. The PNF became almost synonymous with malpractice, with unscrupulous local party officials using their positions to feather their own nests and favour relatives and friends. Nor was the party leadership in any way immune. Indeed, it is hard to find a single senior figure who was not at some point the subject of allegations of serious misconduct.' Christopher Duggan, Fascist Voices: An Intimate History of Mussolini's Italy (Oxford: Oxford University Press, 2013), 231; see also 89, 158, 165, 188. 
Consequently, historical fascism based itself on many anti-Enlightenment values, and while one cannot exclude that its ideological framework contained certain patterns and rhetorical clichés of the Enlightenment, these were less important than the ideological system as a whole.

However, even after accepting the above, one could ask, what is the framework of the anti-Enlightenment tradition today? There are several patterns which make up this value system. At the centre of anti-Enlightenment lies the idea that humans are all different, and they should not be treated equally (this idea got stronger and stronger during the recent refugee crisis). At the centre of this tradition lies the idea that people should not be handled according to their deeds, and they should not be respected as individuals: it stresses the deterministic role of either the ethnic, religious or the cultural background. As Sternhell stated during his acceptance of the Israel Prize, 'The abdication of reason and eruptions of irrationality, the destruction of the idea of the unity of human race are the evils the Enlightenment fought against and these evils were not born in the trenches of the First World War and did not die in Hitler's bunker. Whatever we imagine their future to be, these evils are still part of our world.'33

This core idea can serve as a root for many authoritarian systems and is present in the rhetoric of many far right political streams. Today, racism is usually toned down, but if political streams do not value the individual, they can still use racist clichés. From our perspective, this is interesting, as the core of twentieth century mass murders and modern, 'lighter' 'everyday' racism in Western societies is the same. As a consequence, the anti-Enlightenment tradition degrades the role of freedom and neglects the value of individual rights. Moreover, at a social level, based on this and on Herder's intellectual heritage, the counter-Enlightenment is more about a struggle between nations and cultures (sometimes even religions) instead of individualism, and it overestimates the power of the national myth. More often than not, it also contains fear of national collapse. A good example for this is the speech by Norbert Höfer in Austria, in which he stressed that Austria would cease to exist if he did not win the presidential election. ${ }^{34}$

Zeev Sternhell, 'From Anti-Enlightenment to Fascism and Nazism: Reflections on the Road to Genocide,' (n.p., n.d.), 7, published on Tdziegler Blog, July 19, 2018, https://tdziegler. wordpress.com/2018/o7/19/zeev-sternhell-from-anti-enlightenment-to-fascism-andnazism-reflections-on-the-road-to-genocide/. 
For the counter-Enlightenment tradition, the rationale of human rights is irrelevant and many of these are often harmful for social interests, as its thinking is based on collectivism. The counter-Enlightenment tradition is built on national myths and legends, and that someone must be connected by blood to his/her nation (citizenship is not enough: blood supersedes citizenship). Based on the Sorelian idea, the counter-Enlightenment praises the greatness of the nation and its myths, and instead of analysis, it puts action at the centre: this is why it attacks intellectuals and the press in certain countries. In this system, universalism is swapped for ultra-nationalism. The counter-Enlightenment does not tolerate 'Enlightenment-conformist' liberalism: it sees it as nihilism, because tolerance is not a value to preserve, and it feels tolerance is a kind of moral repression, a nihilist relativism, and as such, liberal dictatorship (or liberal fascism). ${ }^{35}$ This tradition has the potential to completely change a political system and government institutions, to discriminate against or even murder its enemies, or attack other nations. This anti-Enlightenment tradition has gained strength in Europe in the last couple of years and is in fact in conflict with the universalist values on which Western societies were built - to mention just a few examples, the refugee crisis; the number of racist and xenophobic speeches and hate crimes have grown in recent years; ${ }^{36}$ authoritarian tendencies in Eastern-Europe are gradually becoming stronger. ${ }^{37}$ Moreover, false or misleading information (fake news) and online conspiracy theories, the modern forms of irrational myth-making, have also grown more common (around forty per cent of European citizens meet fake news almost every day ${ }^{38}$ ). As Sternhell put it, 'Kant's dream of world peace needs world citizens. ${ }^{39}$ While the desire to become a 'world citizen' seems to be weaker these days, its space is filled with aggressive nationalism in many countries.

35 Snyder calls the phenomenon when fascists call their opponents fascists 'schisofascism'. See Timothy Snyder, The Road to Unfreedom (New York: Tim Duggan Books, 2018), 80-9o, esp. 85 .

36 European Commission against Racism and Intolerance (ECRI), 'Ultra-Nationalism, Antisemitism, Anti-Muslim Hatred: Council of Europe's Anti-Racism Commission Raises Alarm over the Situation in Europe,' February 27, 2020, https://www.coe.int/en/web/ european-commission-against-racism-and-intolerance/-/ultra-nationalism-antisemitismanti-muslim-hatred-council-of-europe-s-anti-racism-commission-raises-alarm-over-thesituation-in-europe.

Daniel R. Kelemen, 'Europe's Other Democratic Deficit: National Authoritarianism in Europe's Democratic Union,' Government and Opposition 52, no. 2 (2017): 211-238. Disinformation', last modified March 12, 2018, https://ec.europa.eu/digital-single-market/ en/news/final-results-eurobarometer-fake-news-and-online-disinformation. 


\section{Generic Fascism, New Consensus and the Anti-Enlightenment Tradition}

After publishing descriptive works on fascism, academia started to collect, analyse and interpret what constituted fascism's basic features during the $1960 \mathrm{~s}$ and 1970s. Several notable authors created lists to define the core of fascism, like Hans Mommsen, ${ }^{40}$ Emilio Gentile ${ }^{41}$ and Stanley Payne, ${ }^{42}$ but one could also add Umberto Eco's widely cited essay on Ur-fascism, ${ }^{43}$ or a 'latecomer', Michael Mann, and his typology. ${ }^{44}$ If we read them carefully, we find several patterns of anti-Enlightenment. For example, numerous authors (like Gentile, Payne and Nolte) highlight that fascism confronted certain other political streams, and strengthened identity politics (fascism was anti-Marxist, anti-liberal, anti-conservative). Several other patterns also fit among the anti-enlightened values. In the case of Payne, for example, these are the creation of a nationalist authoritarian state; the idealist, voluntarist creed; the militarization of political relationships and style; the positive evaluation of violence; the extreme stress on the masculine principle; the exaltation of youth above other phases of life; or the tendency towards an authoritarian, charismatic, personal style of command. ${ }^{45}$ Such inclinations attack not just fascism's physical enemies but egalitarianism, individual thinking and pluralism more generally. This is not only a struggle of ideas, however: it is a kind of enemy-making in a Schmittian sense. In modern electoral autocracies like Russia or Hungary, ${ }^{46}$ the governing far right uses similar patterns in a lighter form, and their enemies are the same or similar groups (especially liberals). In countries where far-right political streams are able to dominate throughout the governmental system, they seem to be less aggressive than historical fascism. There are fewer murders and they do not rely on a movement similar to the black or brown shirts. Walter Laqueur, in his book on Putinism, says that 'historical fascist systems had some

Hans Mommsen, Faschistische Diktatur in Deutschland: Historische Grundlagen, gesellschaftliche Voraussetzungen, politische Struktur (Stuttgart: Klett, 1972).

Emilio Gentile, 'Fascism and the Italian Road to Totalitarianism,' paper presented at the 19th International Congress of Historical Sciences, Oslo, August 6-13, 2000, accessed July 1, 2018, https://www.oslo2ooo.uio.no/program/papers/s12/s12-gentile.pdf, 7 . Stanley G. Payne, Fascism: Comparison and Definition (Madison, London: The University of Wisconsin Press, 1980), 7. Umberto Eco, 'Ur-Fascism,' The New York Review of Books, June 22, 1995, http://www. nybooks.com/articles/1856. Michael Mann, Fascists (Cambridge: Cambridge University Press, 2004), 13. Authoritarianism (Oxford: Oxford University Press, 2015). 
common features, and if some or more of these are not present in them, then it is highly questionable whether these countries could be considered fascist or not: ${ }^{47}$ According to Laqueur, typical fascist patterns would be, for instance, 'the cult of a leader (like Führer or Duce) or the existence of a leading monopolistic party (or ideology). If there is no one-party state, or if there is more than one ideology present, than the form of the power is more likely to be a military or authoritarian dictatorship, and is not necessarily based on fascist principles. ${ }^{48}$ To Laqueur, these are core elements of fascism in a Freedenian sense 49 (i.e. concepts which must be present to talk about fascism). ${ }^{50}$

For comparison, when Der Spiegel asked Sternhell about Russia, he said that

Russia is an autocracy, a semi-dictatorship, which gives a lot of space for Putin to improve. The ingredients of fascism are already there: high level of nationalism, an appeal to the nation, the defence of Russians and the Russian land, racism against 'blacks' in the Caucasus, the re-creation of old strength, the cult of violence and virility, the condemnation of liberalism and the polemic of Western decadence, together with a mendacious propaganda without any restraint. ${ }^{51}$

Consequently, there is a difference between authors who see the use of extreme aggression against opponents as an important factor of fascism and others who stress the ideological (and cultural) roots of exclusion.

It is interesting that in his famous essay, Umberto Eco also mentions many elements which fit into the anti-Enlightenment pattern ${ }^{52}$-for example, the cult of tradition; the 'action first' attitude (instead of rational, fact-based decision-making); the fear of divergence; the suppression of the lower class (fascism could also be interpreted as a reform of the elite and monarchy); and

47 Walter Laqueur, Putyinizmus - Oroszország és jövớje a Nyugattal [Putinism: Russia and Its Future with the West] (Budapest: Atlantic Press, 2016), 199.

48 Ibid.

49 Michael Freeden, 'Political Concepts and Ideological Morphology,' Journal of Political Philosophy 2, no. 2 (1994): 140-164.

50 Please note that Laqueur uses a more creative approach when he talks about Islamist clerical fascism (connecting fascism with Islamism is criticized by Griffin), or when he analyses Russian post-fascism elsewhere. See: Walter Laqueur, Fascism: Past, Present, Future (Oxford: Oxford University Press, 1996), 155 and 192; Roger Griffin, 'What Fascism Is Not and Is: Thoughts on the Re-Inflation of a Concept,' Fascism 2 (2013): 26o, https://doi. org/10.1163/22116257-00202008. Julia Amalia Heyer and Romain Leick, 'Faschismus ist Teil unserer Kultur,' Der Spiegel, July 7, 2014, http://www.spiegel.de/spiegel/print/d-127985806.html. 
the frustration over the wealth and influence of 'enemies'. He adds the pursuit of a permanent mental war, the cult of the 'hero' (everyone must be a hero) and a masculine culture (oppression of women), which also fit into this pattern, including the hatred of individualism.

Mann's basic definition of fascism also contains many such elements (cleansing of intellectual enemies, transcendence, admiration of the state, extreme nationalism). ${ }^{53}$ Apart from a widespread paramilitarism, in a lighter form, these elements are present on the contemporary far right. Many of these elements are part of a European anti-intellectual, anti-rationalist tradition.

Even more interestingly, Payne writes that apart from fascism, in early twentieth century Europe there were other forces which proposed different authoritarian systems. These forces can be divided into the authoritarian radical right and the more conservative authoritarian right. ${ }^{54}$ He separates fascism from these streams (offering a different view about Franco's Spain from Paul Preston, for example ${ }^{55}$ ). This distinction is very interesting, as we can also analyse the patterns which separate fascism from the far right. Payne mentions that these two latter streams put more stress on religion. ${ }^{56}$ However, this seems to be less interesting, as a strict Christian-based democracy could not possibly conform to the values of the Enlightenment (especially with the separation of state and church). Moreover, it seems that unlike political religion in the case of fascism, here original religions fill the same role, which is again an anti-Enlightenment element. This is especially true in light of the findings of Emilio Gentile, who claims that fascism functions as a 'political religion.'57 At the beginning of the twentieth century, religion lost power and influence, resulting in people looking for alternatives, and fascism as a political religion filled this role with its cult-like belief system, religious-like ceremonies and leaders. Payne also mentions that conservative authoritarians only proposed a partial transformation of the political system (for example, they were against parliamentarism) ${ }^{58}$ while the goal of the rhetoric of the radical right was to change the system completely, even if in practice they tended to water down these aims and reorganized monarchism instead. From the perspective

\footnotetext{
53 Michael Mann, Fascists (New York: Cambridge University Press, 2004), 13.

54 Payne, Fascism: Comparison and Definition, 15.

55 Paul Preston, The Politics of Revenge: Fascism and the Military in 2oth Century Spain (London: Routledge, 2005).

56 Payne, Fascism: Comparison and Definition, 17.

57 Emilio Gentile, Politics as Religion (Princeton: Princeton University Press, 2006); Emilio Gentile, 'Political Religion: A Concept and its Critics - A Critical Survey,' Totalitarian Movements and Political Religions 6, no. 1 (2005): 19-32. Payne, Fascism: Comparison and Definition, 18.
} 
of the Enlightenment tradition, this distinction is also of little significance, since a group which is against parliamentarism is probably against joint decision-making and the separation of powers. Payne further mentions that rigid elitism was more common among conservatives and the radical right, ${ }^{59}$ which can also be interpreted as part of the anti-egalitarian (anti-Enlightenment) tradition. While in practice these differences can be very important, from the perspective of Enlightenment ideas, they are not as big as they might seem. The difference between thinking about the destruction of democracy or taking the lead in the destruction is less important if the core idea (abolishing parliamentarism) is the same. The difference between the fact that a new leader or a monarch should be put in control is also irrelevant, as both lack democratic legitimacy. According to Payne, the radical right was also able to receive military support (and 'accept outright pretorianism-rule'60). Conservative and radical right groups, however, could not organize their militias. Fascists were more interested in changing class structures in society than then radical right or authoritarian conservatives, and the conservative authoritarian right was in general less likely to advocate an aggressive form of imperialism. On the other hand, 'in some respects, with regard to violence, authoritarianism, militarism, and imperialism ... the radical right was just as extreme as the fascists, and it was in these respects that the radical right was primarily distinguished from the conservative authoritarian right'.61 Taking an overview of the thinking behind these historical streams, the existence of a strong common framework becomes obvious.

At this point, we must also mention Roger Griffin's definition of fascism. As he put it, 'fascism is a political ideology whose mythic core in its various permutations is a palingenetic form of populist ultranationalism.' ${ }^{62}$ This definition is interesting, as it suggests that a political stream tries to completely reshape a society and eliminate its enemies. However, what is meant by palingenesis? For example, in Hungary, after 2010, all the major laws of the country were replaced, including the constitution, penal code, civil code, electoral laws, regulations concerning municipalities and the judicial system. Even the country's official name was changed, in a telling way, from 'Republic of Hungary' to 'Hungary'. In this change, checks and balances were mostly abolished, and one could certainly call this process 'legal palingenesis' (a rebirth of the legal system). On the other hand, from a legal perspective, Italy's very

$59 \quad$ Ibid.

6o Ibid., 19 .

$61 \quad$ Ibid., 20-21.

62 Roger Griffin, The Nature of Fascism (Oxford, New York: Palgrave Macmillan, 2006), 36. 
basic constitutional and legal structure remained similar to its former stage under Mussolini: for example, the king remained on the throne, and this fact may contradict a complete palingenesis in Italy. ${ }^{63}$ Furthermore, in Hungary, the Declaration of National Cooperation (a document which had to be put on the wall at the entrance to all public offices) contains the following: 'In the spring of 2010 the Hungarian nation once again summoned its vitality and brought about another revolution in the voting booths. The National Assembly declares its acknowledgement and respect of this revolution fought within the framework of the Constitution. ${ }^{64}$

In this text, we see how words are manipulated: it uses the term 'revolution', which normally steps out of the constitutional framework, and later says that the revolution remained constitutional, but created 'a new social contract' called the National System of Cooperation. Of course, Griffin would not accept such a 'revolution' as a real palingenesis, even if its effect is so strong on the society that it created a Russia-like electoral autocracy in Hungary, ${ }^{65}$ a pseudo-multiparty system with the façade of democracy. One can suppose that in order to reach a complete palingenesis in governmental politics, the first step would be to introduce a one-party system. Contrary to this idea, Sternhell stresses the relevance of political power. What he claims is that the question of whether a single party or multi-party system exists in a country is uninteresting. He puts the emphasis on dominance: if one party or group is able to dominate through a seemingly multi-party system, it could create fascism. ${ }^{66}$ This difference between a more formal, political system-based approach and a more content (ideology)-based approach towards fascism is one of the core disputes about the nature of fascism today.

However, whatever we think about a national palingenesis, the idea of a nationalist 'purge' destroying enemies, the extensive use of national myth, abolishing pluralism, tolerance, parliamentarism, attacking other ideologies and countries, and the separation of powers are all part of the anti-Enlightenment tradition Sternhell wrote about, and this idea could be a good common

63 This is so, even if many laws, like the Codice Civile in 1942, were replaced.

64 Political Declaration 1 of 2010 (16 June) of The Hungarian National Assembly on National Cooperation. Text available at http://www.nefmi.gov.hu/political-declaration.

65 Schedler, The Politics of Uncertainty.

66 'For example, people say that if there isn't a one-party regime, it's not fascism. That's nonsense. A party is a means for achieving power, not a means of rule in itself. What needs to be examined in this context is the resilience of the democracy', Gidi Weitz, 'Signs of Fascism in Israel Reached New Peak During Gaza Op, Says Renowned Scholar,' Haaretz, August 13, 2014, https://www.haaretz.com/. premium-signs-of-fascism-in-israel-peaked-during-gaza-op-1.5259272. 
denominator among different views. Moreover, Griffin's idea of a palingenesis could be interpreted in the light of Sternhell's theory as a process through which the anti-Enlightenment idea, which was already present in the society, gains power and changes the former more or less enlightened principles of governance. As such, this palingenesis could be interpreted as a radical reformulation of anti-Enlightenment ideas into a completely new system, thereby creating a compromise between the two seemingly contradictory interpretations.

\section{Post- and Neo-Fascism and their Connection to the Anti-Enlightenment Tradition}

Griffin also highlights that certain political parties like the National Front (now National Rally in France) borrow language from neo-fascists, and stresses that these parties are reformist rather than revolutionary. ${ }^{67} \mathrm{He}$ thinks this because the level of aggression in the palingenetic process is different (these far-right streams advocate an incomplete palingenesis). Moreover, in Griffin's interpretation, several post-fascist parties remain within the democratic framework. He published a widely cited article about Alleanza Nazionale (AN) in $1996 .{ }^{68}$ What is very interesting is his claim that some parties create a kind of 'constitutional fascism' - an ideological system which remains in the framework of the democratic environment, but which still contains many fascist elements. In the case of AN, these were the attack on materialism; embodying healthy pro-life values of the family and youth; anti-partocracy (anti-elitism); portraying themselves as the defenders of faith; the rejection of secularism and relativism; attack on consumerism; the myth of the ethical state; the claim that 'Italianness is not to be confused with citizenship'; 69 and revisionism. Griffin maintains that these patterns remain within a constitutional framework, which is why he talks about post-fascism instead of neo-fascism. However, he accepts that their ideological roots lie in fascism: in this regard, his approach is similar to that of Finchelstein (see below). If we check the fascist elements Griffin writes about, it seems many of them go against Enlightenment values. For example, the excessive respect for the youth means disrespecting the

\footnotetext{
$67 \quad$ Griffin, The Nature of Fascism, 148.

68 Roger Griffin, "The "Post-Fascism" of the Alleanza Nazionale: A Case Study in Ideological Morphology,' Journal of Political Ideologies 1, no. 2 (1996): 123-145, https://doi. org/10.1080/13569319608420733.

69 Roger Griffin, 'The 'Post-Fascism' of the Alleanza Nazionale,' author's version, 17, available at https://www.researchgate.net/publication/232860243_The_'post-Fascism'_of_the_ Alleanza_Nazionale_A_case_study_in_ideological_morphology, accessed 15 June 2020.
} 
elderly, which can lead to disrespecting individualism, intellectualism and intellectuals. Excessive respect for ethnic 'Italianness' means disrespecting other ethnic groups and can lead to open racism and xenophobia. Moreover, one cannot maintain individual liberty in a moralizing state which intrudes into the private sphere of the individuals. This is also why it is questionable whether virulent anti-Enlightenment patterns can belong to the democratic realm at all. A typical modern example of this is the case of Hungary, where anti-refugee policies (like detaining refugees, even children and persons with diabetes, in transit zones without food) are mixed with authoritarian tendencies. $^{70}$ The case of Poland is similar, where latent antisemitism and authoritarianism are connected..$^{71}$ Probably, the reason for this is that, in many cases, if political forces do not respect the individual's dignity, they will not respect the political groups these individuals create either, thereby breaking the fundaments of pluralism in the society.

To the analysis above, one should add Marxist perceptions of fascism and post-fascism. In many of them, we find the idea of an oppressive capitalist elite which tries to push down the poor in a society and uses state power in order to do so. ${ }^{72}$ Whatever we think about this idea, it also contains an interesting element-namely, that an elite, surrounding an emperor, a king, or a strong leader, oppresses the poorer or more vulnerable groups of society through controlling economics. This element blocks egalitarianism, at least in the economic sense, and it blocks social mobility and serves authoritarian terror. A form of this idea is reflected when scholars connect the rise of populism to economic problems. ${ }^{73}$ Furthermore, recent neo-Marxist interpretations of post-fascism are also interesting. Gáspár Miklós Tamás, for example, equates post-fascism with the denial of universal citizenship-i.e. the return of perceptions of

70 The Hungarian Helsinki Committee, 'Hungary Continues to Starve Detainees in the Transit Zones,' April 23, 2019, https://www.helsinki.hu/en/ hungary-continues-to-starve-detainees-in-the-transit-zones/.

71 Paul Mason, 'Poland is Rewriting History - and the Consequence is the Rise of Anti-Semitism,' New Statesman, June 13, 2018, https://www.newstatesman.com/world/ europe/2018/o6/poland-rewriting-history-and-consequence-rise-anti-semitism; Hank Reichmann, 'Academic Freedom Threatened in Poland,' Academe Blog, February 19, 2016, https://academeblog.org/2016/o2/19/academic-freedom-threatened-in-poland/.

Georgi Dimitrov, 'The Fascist Offensive and the Tasks of the Communist International in the Struggle of the Working Class against Fascism: Main Report Delivered at the Seventh World Congress of the Communist International, Delivered on August 2, 1935,' in Georgi Dimitrov, Selected Works (Sofia: Sofia Press, 1972).

73 Inglehart and Norris mention several such theories. See Inglehart and Norris, 'Trump, Brexit, and the Rise of Populism.' 
citizenship as a privilege. ${ }^{74}$ In his interpretation, this notion returns with the rise of post-fascist parties, which do not necessarily amend the institutional framework around them, but still favour social exclusion. Even though the latter is a more nuanced analysis, the theory also mixes economic oppressions with ethnic exclusion and points out how post-fascism attacks égalité, one of the core concepts of the Enlightenment.

Moving on to neo-fascism, we find that interpretation of the term is even more diverse. Walter Laqueur believes that the new fascists try to maintain some older ideas of fascism by renewing some of its old content. ${ }^{75}$ There are many social patterns which are similar to older times. For example, Laqueur mentions the modern propaganda in certain countries like Berlusconi's Italy. This propaganda could be interpreted as something seeking to eliminate Enlightenment-style, rationalist decision-making, and even limits the will of the people. Laqueur claims that neo-fascist groups promote the defence of Europe instead of military action (like historical fascism), are anti-elitist and attack the political elite as a whole. Emotional politics, and especially authoritarianism and the oppression of others, are also values belonging to the anti-Enlightenment tradition. Neo-fascists are extremely nationalistic and anti-capitalist (but they do not define clearly how they would diverge from neoliberal economics). They try to defend the middle class against big business. They support law and order policies and usually demand effective actions against crime. From a religious perspective, it is a heterodox community: some are Christians, others are not religious at all. Their ideology is based on myth and does not stress intellectualism: they do not necessarily know the intellectual leaders of the New Right known Europe-wide, like Julius Evola or Alain de Benoist. ${ }^{76}$

G.M. Tamás, 'On Post-Fascism: The Degradation of Universal Citizenship', Boston Review, June 1, 200o, http://bostonreview.net/world/g-m-tamas-post-fascism; Erik de la Reguera, 'Gáspár Miklós Tamás: This is Post-Fascism,' Arbetet, September 26, 2015, http://arbetet.se/ global/2015/og/26/gaspar-miklos-tamas-this-is-post-fascism/; G.M. Tamás, 'What is PostFascism?' Open Democracy, September 14, 2001, https://www.opendemocracy.net/peoplenewright/article_306.jsp. The idea of an oppressive capitalist regime is also reflected in Bertram Gross, Friendly Fascism: The New Face of Power in America (Montreal: Black Rose Books, 1980). As Charles Henry put it, 'Gross was concerned that the ever-closer integration of Big Business and Big Government could well lead to a new, kinder, gentler form of fascism - a fascism that promised citizens cheap and plentiful material goods in exchange for civil and political rights.' Charles Henry, 'Donald Trump and Friendly Fascism Reconsidered,' Berkeley Blog, August 7, 2015, https://blogs.berkeley.edu/2015/08/o7/ donald-trump-and-friendly-fascism-reconsidered/.

76 Thomas Sheehan, 'Myth and Violence: The Fascism of Julius Evola and Alain de Benoist,' Social Research 48, no. 1 (Spring, 1981): 45-73. 
Finally, some good examples of anti-Enlightenment values can be traced in Tamir Bar-On's analysis of Alain de Benoist. Bar-On selects patterns like the fear of foreign powers; the decadence of liberal universalism and capitalism; Europe as a 'pagan' tribe against egalitarian influences; the rejection of multiculturalism and immigration (the desire for a racially homogeneous community, a kind of cultural racism); the idea of fatigue and decadence; the desire for a new elite; the rejection of the liberal, capitalist, and technocratic model of the EU' and a Europe which should 'regulate globalization.' ${ }^{77}$ In Tamir Bar-On's interpretation, this new fascism is a modern form of its historical predecessors. ${ }^{78}$

\section{The Far Right and the Anti-Enlightenment Tradition}

It is a highly interesting intellectual exercise to track the patterns of the anti-Enlightenment tradition in the works of scholars who wrote about the far right. According to Piero Ignazi, for example, from the beginning of the 1980s, fascist ideas played only a minor role in shaping the image of the extreme right, and many groups were more influenced by new right-wing and neoconservative views. ${ }^{79}$ In his opinion, new groups also appeared which did not have their roots in fascism. This idea does not take into consideration that the core of authoritarian conservatism (as proved above) is also based on many anti-Enlightenment ideas, and as such, it had a very strong effect on historical fascism.

Populism as a phenomenon does not have a uniform interpretation in science. According to Cas Mudde, we must differentiate between extreme right and populist radical right political groups. As he puts it, 'the extremist right-wing parties are more anti-democratic, often elitists, while on the other hand, the radical populist right-wing parties are nominally democratic and populist'. ${ }^{80}$ Consequently, Mudde believes that the thin line between them

Tamir Bar-On, 'Alain de Benoist: Neo-Fascism with a Human Face?' Konferenzpapier zum Vertiefungsangebot 'Grenzübergreifende Konzepte der radikalen Rechten' im Rahmen der Fachtagung 'Entgrenzter Rechtsextremismus? Internationale Perspektiven und Gegenstrategien' der Bundeszentrale für politische Bildung in München, February 9-10, 2015,5 .

78 Tamir Bar-On, Where Have All the Fascists Gone? (Aldershot: Ashgate, 2007).

79 Piero Ignazi, Extreme-right Parties in Western Europe (Oxford: Oxford University Press, 2003), 24 .

80 Cas Mudde, Populist Radical Right Parties in Europe (Cambridge: Cambridge University Press, 2007), 49. 
is similar to what Payne said about the radical right and authoritarian conservatives decades earlier. This is also why Mudde claims that what he calls 'populism' is not against democracy, and why these parties remain in the democratic realm. In his interpretation, populism is a thin-layered ideology which contains a mix of anti-elitism, high level emotions, nationalism and ethnicism, probably also racism, but it does not contain an extensive set of ideological values.

On the other hand, Nigel Copsey claims, contrary to Mudde, that 'neo-fascism represents a continual evolution of fascism away from its dominant inter-war manifestations. . . . In this sense, some neo-fascists do possess "open minds" and this is no "lunatic fringe." ... Radical right-wing populism (if we want to persist with this label) has grown in sophistication largely due to the influence of neo-fascist theorists, particularly with regard to the adoption of ethno-pluralist discourse.' 81

One can also easily ascertain that Mudde's claim concerning the democratic nature of populism seems to be false from an empirical point of view: in the two European countries where far-right parties received enough votes to make major changes to the governmental and constitutional system (Hungary and Russia), they were able to create autocracies relatively quickly, and Poland is also heading in this direction. The picture is even darker if we add the activity of Erdogan's Adalet ve Kalkinma Partisi (AKP) to it, which brings the country towards a full-fledged totalitarian system..$^{82}$ The AN and the Liga in Italy or FPÖ in Austria never received enough votes to completely dominate in the Parliament and be able to change the constitutional and governmental system of their countries. The same is true of Donald Trump, whose actions were limited by the checks and balances in the US. The other problem is that we can hardly state that a political group remains in the framework of constitutional democracy if it has racist ideas and goes against this basic core of the Enlightenment tradition: this is why Copsey's last sentence on the 'ethno-pluralist discourse' is so important. Moreover, attacking 'enemies' (the elite) and claiming that they do not belong to the nation, or using demonizing, dehumanizing rhetoric, ${ }^{83}$

81 Nigel Copsey, "Fascism... but with an open mind": Reflections on the Contemporary Far Right in (Western) Europe,' Fascism 2 (2013):1-17, https://doi.org/10.1163/22116257-00201008. Cihan Tugal, 'Turkey Coup Aftermath: Between Neo-Fascism and Bonapartism,' Open Democracy, July 18, 2016, https://www.opendemocracy.net/cihan-tugal/turkey-coupaftermath-between-neo-fascism-and-bonapartism; Cihan Tugal, 'In Turkey, the Regime Slides from Soft to Hard Totalitarianism,' Open Democracy, February 17, 2016, https://www. opendemocracy.net/cihan-tugal/turkey-hard-totalitarianism-erdogan-authoritarian.

83 Éva S. Balogh, 'Viktor Orbán's Speech: War Against The World, Hungarian Spectrum, March 16, 2016, http://hungarianspectrum.org/2016/o3/16/viktor-orbans- 
are against the Enlightenment tradition, and it shows that the group applying these techniques is against pluralism and tolerance. This is why Simon WrenLewis writes that " $\mathrm{i}] \mathrm{t}$ seems to me that a quite different conceptualisation of populism is expressed by Jan-Werner Müller. ${ }^{84}$... The populist, if you accept Müller's account, denies pluralism. They are naturally authoritarian, and so are happy to tear down the elements of a pluralist democracy. ${ }^{\prime 25}$ No wonder, in his book on populism, Jan-Werner Müller describes Nazi features and scholars as populists. Populists, in his interpretation, are attacking the elites, are anti-pluralist, represent a form of identity politics, and attempt to hijack the state apparatus, increase corruption and build mass clientelism. ${ }^{86}$

In addition to the above, Roger Karapin believes that the common segment of fascism and the radical far right is the nationalist critique of ethnicities/ minorities, attacks against the political class and the elites, and the appeal for a stronger power or authority. ${ }^{87}$ One can ascertain that these features form the anti-Enlightenment core among these streams. However, in Karapin's opinion, the differences between fascists and the radical right have significantly more importance than these features. In his opinion, the radical far right focuses on issues such as immigration, and, with some exceptions, does not care about border disputes and revisionism. (This statement is incorrect: see the Hungarian, the Russian, or the Austrian far right, or the AN at the beginning of the 199os in Italy. In all of these groups, revisionism played a very important role. Moreover, the core of xenophobia is the denial of universal humanity, just like in fascism). In addition, Karapin claims that the authoritarianism of the radical right centralizes milder, more democratic systems, which desire

speech-war-against-the-world/; Maya Oppenheim, 'Hungarian MP Accused of Antisemitism over Photo of Dead Pig Inscribed with "Soros", The Independent, December 10, 2017, http://www.independent.co.uk/news/world/europe/george-soros-deadpig-janos-pocs-facebook-viktor-orban-a8102341.html; Benjamin Novak, 'EPP Deputy Chairman Compares Refugees to Zombies from Game of Thrones,' Budapest Beacon, October 30, 2017, https://budapestbeacon.com/epp-deputy-chairman-compares-refugeeszombies-game-thrones/; Éva S. Balogh, 'They Don't See Eye To Eye: Pope Francis and the Hungarian Bishops,' Hungarian Spectrum, December 17, 2017, https://hungarianspectrum. org/2017/12/27/they-dont-see-eye-to-eye-pope-francis-and-the-hungarian-bishops/.

84 Jan-Werner Müller, 'How Populists Win When They Lose,' Social Europe, June 29, 2017, https://www.socialeurope.eu/populists-win-lose.

85 Simon Wren-Lewis, 'The Two Types of Populism within Brexit,' Mainly Macro, February 9, 2018, https://mainlymacro.blogspot.com/2018/o2/the-two-types-of-populism-withinbrexit.html.

86 Jan-Werner Muller, What is Populism? (Pennsylvania: University of Pennsylvania Press, 2016).

87 Roger Karapin, 'Radical-Right and Neo-Fascist Political Parties in Western Europe,' Comparative Politics 3o, no. 2 (1998): 218. 
strong leadership without any fundamental constitutional changes (another questionable claim: see the above-mentioned examples). Karapin also thinks that, as opposed to the fascist parties, radical right parties support neoliberal economic policies, criticize the social state and demand more economic freedom. About this argument, Copsey writes that: 'although political scientists went on to criticize both Kitschelt and Betz for overstating the extent to which radical-right populist parties espoused neo-liberal economic programmes-in fact one, Cas Mudde, argued that their economic programmes were not neo-liberal at all but nativist. ${ }^{\prime} 8$

In many authoritarian countries from the beginning of the twenty-first century, very similar economic systems were created to that in Fascist Italy, mixing paternalism, protectionism, nativism (in the form of the support of certain government-friendly oligarchs) and free market policies. ${ }^{89}$ The parallel becomes more interesting if you read the complaints of businessmen discriminated against between the world wars and compare them to present day oligarchization..$^{90}$ Finally, Karapin mentions that the parties of the far right are framework parties with strong leaders and centralized organization but with fewer members, and they solely focus on elections. One could have serious doubts about this statement as well, as it mostly describes the Front National but not necessarily all the other far right parties in Europe. Moreover, because of authoritarian thinking, most of these parties are centralized and have strong leaders, even if the 'leader cult' is not present necessarily in all of them.

Another thought-provoking approach is followed by Federico Finchelstein. He claims that populism had an ideological pendulum with central features, like 'an extremely sacralizing understanding of the political'; 'the people as being formed by those who follow a unique vertical leadership'; the idea of enemies who are traitors to the nation; the leader who is the embodiment of the 'voice and desires of the nation'; the dismissal of the legislative and judicial branches of government; a mainstream culture of radical nationalism; and 'a vertical form of electoral democracy that nonetheless rejects ... dictatorial forms of government. ${ }^{91}$ Most elements on this list could be cited as basic values going against the Enlightenment tradition, including the sacralization

88 Copsey, "Fascism... but with an open mind", 9 .

89 Bálint Magyar, The Post-Communist Mafia State: The Case of Hungary (Budapest: CEU Press, 2016); Tamas Dezso Ziegler, 'The Links Between Human Rights and the Single European Market: Discrimination and Systemic Infringement,' Comparative Law Review 7 , no. 1 (2016): 1.

$90 \quad$ Günter Reimann, The Vampire Economy: Doing Business Under Fascism (Auburn: Ludwig von Mises Institute, 1939).

$91 \quad$ Federico Finchelstein, 'Returning Populism to History,' Constellations 21, no. 4 (2014): 468. 
of politics (instead of rationalizing it), the idea of traitors to the nation (the desire to eradicate ideas), charismatic leadership and radical nationalism. Furthermore, even more interestingly, Finchelstein also claims that ' $[\mathrm{M}]$ odern populism was born out of fascism .... After the War, populism reformulated the legacies of the 'anti-Enlightenment' for the Cold War era ... Fascism put forward a violent totalitarian order that led to radical forms of political violence and genocide. In contrast, and as a result of the defeat of fascism, populism attempted to reform and retune the fascist legacy to a democratic key'. ${ }^{2}$

The relevance of this argument is that in Finchelstein's interpretation even though 'modern populism is a post-war reformulation of post-fascism', populism remains within the democratic realm. ${ }^{93}$ Consequently, even though many populist parties want the destruction of the European Union, he supposes that they would not destroy democracy, but 'only attempt to limit its reach and curtail its emancipatory potential. ${ }^{94}$ This idea could be very important in respect of our topic. In an interview, Finchelstein also simplified his stance, claiming that the key difference between populism and actual fascism is the use of violence. As he put it, 'populism combines low level actual violence with high level rhetorical violence,' applying it to an authoritarian way of understanding democracy: 'fascism is never a democracy, while populism undermines democracy, but doesn't remove it. 95

\section{The Social Psychology of the Anti-Enlightenment}

An often-neglected factor regarding the analysis of the far right and fascism is the fact that scholars ${ }^{96}$ researching the psychological background of fascism do not differentiate between the psychology of fascism and that of the far right. Most of them talk about authoritarianism in a broad sense. The reason for this is that psychological processes are more or less the same in these streams.

As Robert Paxton illustrates in his book on the anatomy of fascism, the mobilizing passions of fascism are hard to treat historically, for many of them

92 Federico Finchelstein, From Fascism to Populism in History (Berkeley: University of California Press, 2018), 12.

93 Finchelstein, 'Returning Populism to History', 469.

$94 \quad$ Ibid., 478.

95 Annalisa Merelli, 'The Key Difference between Populism and Fascism,' Quartz, November 29, 2016, https://qz.com/847040/the-key-difference-between-populism-and-fascism/.

96 Edgardo Etchezahar, Silvina Brussino, 'Psychological Perspectives in the Study of Authoritarianism,' Journal of Alternative Perspectives in the Social Sciences 5, no. 3 (2013): 495-521. 
are as old as Cain. 'It seems incontestable, however, that the fevers of increased nationalism before World War I and the passions aroused by that war sharpened them,.${ }^{97}$ If we check Paxton's list of these passions, we see many of them could also be part of far right politics. The belief in the primacy of the group and the group's victimhood are common, just like the dread of cultural decadence, individualism and liberalism. The same could be said about the closer integration of the community by maintaining purity and unity: for example, in Hungary, the official government propaganda wants to beat immigration by pushing citizens to give birth to more children, just like in fascist Italy (for Mussolini, birth rates and the health of the nation were connected. As he stated, 'all nations and all empires have felt the teeth of decadence sinking into them when they have seen their levels of natality fall'). ${ }^{98}$ The grandeur of the group reinforced in (sometimes rootless) individual self-esteem, or the creation of a national chieftain, are also not new. It is enough to think about the czar, later the role of Stalin, or now about Putin — no wonder Laqueur believes such a character would exist without Putin in Russia, because it reflects the desires of the people. ${ }^{99}$ The same can be said about the right of the chosen people to dominate others without restraint from any kind of power, human or divine. Liking the beauty of violence is rather pushed into the background in European politics, so this may be an exception. We can easily admit that many of these passions are contrary to enlightened ideals and show a picture of a person who loses his/her rationality but tries to regain some self-esteem through exaggerated nationalism, hatred of other nations and other people, and a desire to be led. ${ }^{100}$ If we examine scholars one by one, we can find different forms of this pattern.

In the theory of Wilhelm Reich, we find religious, irrational zeal transferred into sexual oppression as a cause of authoritarian personality. ${ }^{101}$ This goes against the enlightened rationale and the secular state. In the case of Fromm, we find loneliness at the centre: the hopeless individual seeks security, looks for orientation which was lost with the expulsion of religion from the public sphere. ${ }^{102}$ Great freedom will result in an unbearable burden, so the individual

\footnotetext{
97 Robert Paxton, The Anatomy of Fascism (New York: Alfred A. Knopf, 2004), 42.

98 Cristopher Duggan, Fascist Voice: An Intimate History of Mussolini's Italy (London: Vintage Books, 2013), 123 .

99 Laqueur, Putyinizmus, 79.

100 Gilles Deleuze and Felix Guattari, Anti-Oedipus: Capitalism and Schizophrenia (Minneapolis: University of Minnesota Press, 1972).

101 Wilhelm Reich, Mass Psychology of Fascism (New York: Farrar, Straus and Giroux, 1939).

102 Erich Fromm, Escape from Freedom (New York: Farrar \& Rinehart, 1942).
} 
needs someone to adore in a masochistic way: the great leader. Adorno ${ }^{103}$ and Altemeyer ${ }^{104}$ describe many similar patterns. According to the latter, the three pillars of authoritarianism are authoritarian submission, authoritarian aggression and conventionalism. Submission is the desire to pull down other political streams, a widespread desire in far right politics. Fear and irrationality also tend to overcome persons with more authoritarian attitudes. Authoritarian personalities tend to react more strongly to crises; they cannot differentiate between possible and actual danger. Also, they are convinced that the majority is on their side, believing that they are part of a supreme group with higher morals than the rest of the society. If they are religious, in many cases this strengthens that mentality. The desire to oppress others because of their opinion, the desire for conformity instead of respecting the individual's dignity and their opinion (disrespecting the freedom of belief), is another anti-Enlightenment pattern. In most cases, authoritarians are led by socially dominant, highly manipulative personalities, which is another common anti-Enlightenment pattern between fascism and far right streams: ${ }^{105}$ as Altemeyer puts it, 20 to 25 per cent of Americans would support a demagogue leader who acts against minorities in the pursuit of power. ${ }^{106}$

Karen Stenner also mentions that there are differences between authoritarians, conservatives and libertarians. ${ }^{107}$ As she puts it,

[I]n the end, then, authoritarianism is far more than a personal distaste for difference .... This worldview induces both personal coercion of and bias against different others (racial and ethnic outgroups, political dissidents, moral 'deviants') as well as political demands for authoritative constraints on their behavior. The latter will typically include legal discrimination against minorities and restrictions on immigration, limits

Theodor Adorno et al., The Authoritarian Personality (New York: Harper \& Brothers, 1950). Bob Altemeyer, The Authoritarians (Winipeg: the author, 2006), available at https:// theauthoritarians.org/options-for-getting-the-book/, accessed July 1, 2018.

Bob Altemeyer, 'The Other Authoritarian Personality,' Advances in Experimental Social Psychology 30 (1998): 47-92; Felicia Pratto, Jim Sidanius, Lisa M. Stallworth and Bertram F. Malle, 'Social Dominance Orientation: A Personality Variable Predicting Social and Political Attitudes,' Journal of Personality and Social Psychology 67, no. 4 (1994): 741-776.

'Bob Altemeyer has a New Web Site and a Revised Article on Donald Trump and Authoritarian Followers,' Daily Kos, August 5, 2016, http://www.dailykos.com/ story/2016/8/5/1556975/-Bob-Altemeyer-has-a-new-web-site-and-a-revised-article-onDonald-Trump-and-Authoritarian-Followers.

Karen Stenner, The Authoritarian Dynamic (Cambridge: Cambridge University Press, 2005); Karen Stenner, 'Three Kinds of "Conservatism", Psychological Inquiry 20, no. 2-3 (2009): 142-159. 
on free speech and association, and the regulation of moral behavior, for example, via policies regarding school prayer, abortion, censorship, and homosexuality, and their punitive enforcement. ${ }^{108}$

As such, authoritarianism is basically different from status quo conservatism, which respects democracy and the Enlightenment tradition.

Finally, one can add the recent literature about social identity theory. Some of the latest representatives of this stream have written magnificent essays on how a strong leader is able to fascinate voters. ${ }^{109}$ This is noteworthy because it reconnects to Sternhell's theory. Social identity theorists maintain that the leader of a nation is a projection of the values of his followers ${ }^{110}$ (and as such, of the society itself). From this perspective, Mussolini was not merely a political gambler in Italy: he tried to absorb Italians' feelings, from lost wars in Africa to the idea of a nation which deserved a better fate because of its great culture and great inventions and the desire for more land and more influence. In sum, he was able to project a unique kind of 'Italianness', accepted by many in Italy at the end of the First World War, even if they did not like his political programme. The same is true concerning far-right leaders: when Vladimir Putin poses with tigers he shot, or when Viktor Orbán goes to a sausage-filling competition, they all try to represent themselves as the projection of the values of everyday people. Consequently, the micro scope of researches and macro picture of culture and social patterns are connected. This has grave consequences, as many of the authoritarian followers will give up rational analysis for emotions and will excuse these leaders, who they feel are one of them, representing the values they believe in.

\section{The Necessity of the Re-Interpretation of the Fascist Universe}

This article interpreted fascism as a nationalistic, authoritarian ideological framework built on the values of the anti-Enlightenment tradition. After discussing different theorists on fascism and the far right, it argues that most of the members in both groups have the same or very similar ideas, which have their roots in the anti-Enlightenment tradition. This is also shown in Griffin's

\footnotetext{
108 Stenner, 'Three Kinds of "Conservatism", 143.

109 Alexander Haslam, Stephen D. Reicher and Michael J. Platow, The New Psychology of Leadership: Identity, Influence and Power (Hove, New York: Social Psychology Press, 2010).

110 Guy Elcheroth and Stephen Reicher, Identity, Violence and Power: Mobilising Hatred, Demobilising Dissent (London: Palgrave Macmillan, 2017), 39 et seq.
} 
important article on AN and by Finchelstein's article on populism. Just like in the works of Mudde, in the conceptualization of Griffin and Finchelstein, 'constitutional fascism' or 'populism' remain within the democratic framework, even if either their ideology or their rhetoric contains patterns resembling historical fascism. I personally disagree (or, to be more precise, only partly agree) with this view, and believe we should set up a completely new model and a structural approach to examining far-right political streams. The reason for this is that the anti-democratic, anti-Enlightenment ideological tenets present in these groups can hardly be associated with the basics of modern democracy, and if these groups are loyal to their values, it can lead to the abolition of democracy in most of cases.

Please also note, however, that the existence of a common framework between fascism and the far right does not deny the fact that far-right political groups can implement ideas into their political repertoire that conform with the Enlightenment, or at least use them as mimicry (or both). A good example of this is when they oppose Islamism (i.e. religious fundamentalism), or support the separation of state and religion or tolerance towards same-sex partnerships and marriages. ${ }^{111}$ However, when they use an indiscriminate portrayal of Muslims, they breach one of the most important rules of the Enlightenment: the fair and individualistic treatment of people. There are Muslims who are not against liberal democracy and hiding this goes against their basic human dignity. As mentioned before, I believe the disrespect of human dignity has the potential to unfold later: if such forces gain governmental position, it can lead to authoritarianism. If you do not respect the human dignity of everyone, there is a high chance you will not respect pluralism either, because it is also based on the respect of the individual. This way, intolerance can spill over into different fields. On the other hand, I also agree with Tamir Bar-On that there is enough room to criticize fundamentalist (totalitarian) Islam, or even to compare it to fascism, ${ }^{112}$ especially as fundamentalist religions have many anti-Enlightenment patterns similar to fascism (such as denying the equality of all humans; denying the equality of men and women; creating hierarchical social structures; connecting law, state and religion; disrespecting checks and Political Ideologies 13, no. 3 (2008), 321-344; Lars Erik Berntzen, Liberal Roots of Far Right Activism: The Anti-Islamic Movement in the 21st Century (London: Routledge, 2019), 1-20, 113-134; Lars Erik Berntzen and Sveinung Sandberg, 'The Collective Nature of Lone Wolf Terrorism: Anders Behring Breivik and the Anti-Islamic Social Movement,' Terrorism and Political Violence 26, no. 45 (2014), 759-779. 
balances, to mention only a few). However, such criticism may not be done in an undifferentiated manner, attacking everybody who is religious or belongs to a certain religion. ${ }^{113}$

Furthermore, I believe that the present state of political liberalism can also be criticized, and such criticism does not necessarily mean that the critics belong to the anti-Enlightenment tradition per se. For example, both Pierre Rosanvallon and Wolfgang Streeck highlight our pseudo-technocratic decision-making in modern states, where important questions are portrayed as questions where there is no space for public discussion (Rosanvallon calls this 'unpolitical democracy'). ${ }^{114}$ Such questions can be related to economic policies (like the weakening of the social state), but one could also mention the case of same-sex marriage, abortion or euthanasia, or the case of participating in military conflicts outside Europe. Criticizing this 'apolitical state', in my opinion, is not harmful, as it can strengthen pluralism, tolerance and the democratic legitimacy of decision-making. Isaiah Berlin was right to claim that we should not move into an authoritarian, predestined-type of rationality, where there is only one good solution to every social issue. ${ }^{115}$

Returning to fascism and the far right, a good example of the common anti-Enlightenment framework of far right and fascism is the oppression of the free press. Of course, there is a great difference between Donald Trump, who attacks journalists, talks about 'fake news' and bans journalists from entering the White House, and Russia, where opposition journalists are shut down or poisoned, or Hungary, where the governing party is able to control the greatest part of the printed press through newspaper acquisitions and spending

113 I disagree with Enzo Traverso, who claims that actions like the burka ban in France are harmful, radicalized post-Enlightenment measures, even though I accept his argument that Islamophobia in Europe becomes something very similar to anti-Semitism before the Second World War. I believe the Enlightened principle of laïcité may be defended through such measures against religious streams which oppress women and would presumably attack the state, as they do not accept separation of state and religion and disrespect human dignity. It is, however, a different question how much European states separate religion and state in their own legal systems concerning Christianity: for example, in many countries, religion is weaponized and used to strengthen xenophobia, and in several countries, the state also collects religious tax. As a result, in Germany, the state decides whether someone can be seen as Jewish or not. See Ronen Reichman, 'Israel: Religion oder Abstammung? Warum sich das Oberste Gericht mit der Frage beschäftigt, wer Jude ist,' Jüdische Allgemeine, May 18, 2018, https://www.juedische-allgemeine.de/religion/religionoder-abstammung/; Enzo Traverso, The New Faces of Fascism (London: Verso, 2019), 48.

114 Pierre Rosanvallon, Counter-Democracy: Politics in an Age of Distrust (Cambridge: Cambridge University Press, 2008), 249 et seq; Wolfgang Streeck, 'The Return of the Repressed,' New Left Review 104, no. 3-4 (2017): 1-18. 
billions on government-friendly media, thereby introducing a kind of virtual censorship. None of them is completely similar to historical fascism, where the editorial offices of Avanti were attacked and set on fire, and the free press later banned. But the basic idea-including the denial of pluralism and tolerance, the hatred of the 'enemy', and the desire for its subversion and silencing-is very similar. If a political force wants to adhere to this idea, that can lead to modern-day oppression. This oppression does not necessarily result in a totalitarian state, but it can result in autocracies like Hungary or Russia. Such forces mostly remain within the realm of democracy, if either they feel they would lose public support by adopting a more open rhetoric, or the democratic framework of the country blocks their actions. For example, in the US, Donald Trump cannot rule alone: in the US constitutional structure the president is just one institution, and the Congress, the Supreme Court and the states' power all very seriously limit his power and political leeway. Consequently, such parties and groups do not necessarily limit themselves, but are limited by their circumstances and the pacifying democratic environment. As a result, they adhere to certain democratic principles, thereby (either honestly or dishonestly) accepting some basics of the Enlightenment tradition (like formally accepting the competitive multi-party system, check and balances, or certain forms of individualism).

Anti-Enlightenment elements can be present in nearly any political stream's repertoire, even if they do not form a complete system. For example, some such elements, like hatred towards liberal individualism, were present in Stalinism and many radical leftist groups. Authoritarian conservatives also had views which went against the Enlightenment: for example, many of them did not support the separation of religion and state, or demanded an authoritarian, post-feudal form of governance. Today, some anti-Enlightenment elements, like aggressive nationalistic clichés, are occasionally used by democratic parties as well, and Steven Pinker mentions that radical environmentalism can also contain patterns (like irrationalism, mythic culture and authoritarian techniques). ${ }^{116}$ Moreover, even policies intended to strengthen enlightened universalism can backfire and strengthen anti-Enlightenment sentiments: for example, the affirmative actions in the US, which have the potential to stress race over equality, can strengthen the idea that there are some kinds of 'good race.'17 This is interesting because social processes can sometimes strengthen

116 Steven Pinker, Enlightenment Now: The Case for Reason, Science, Humanism, and Progress (New York: Viking, 2018), 29.

117 See Francis Fukuyama, Identity: Contemporary Identity Politics and the Struggle for Recognition (London: Profile Books, 2018), 105 et seq. 
each other. For example, common acceptance of xenophobic or racist positions, or democratic fatigue, or authoritarian techniques has the potential to pull a society into a direction which goes against Enlightenment values. The presence of these elements on the far right is by far more overwhelming than in other political streams.

This is also the reason that scholars have tried to explain for decades why many far-right streams differ from fascism, albeit rather unsuccessfully. When Sternhell talked about Trump, he mentioned that his nationalism, illiberalism and, especially, his hostile attitude towards human rights are common points with fascism, but he also added that he considers fascism to be a genuinely European phenomenon. ${ }^{118}$ I disagree with him, as very strong anti-Enlightenment patterns were present in the US even before the recent past: for example, the struggle for African-American people's rights lasted until the 196os, and, as Eric Foner perfectly explains, the term 'freedom' had to be re-interpreted again and again to broaden its scope to every human being. ${ }^{119}$ One could also add different elements of authoritarianism and economic protectionism to this list: this means that Michael Mann is wrong to belittle the obvious anti-Enlightened patterns in Donald Trump's politics and claim that Trump does not have an ideology at all. ${ }^{120}$

However, it is obvious that if anti-Enlightenment elements play only a limited role, we can hardly connect a group to fascism. For example, moderate conservatives may have superficial xenophobic sentiments and most commentators still would not call them fascists. On the other hand, if these patterns form an authoritarian cognitive system, it is necessary to connect the related political groups to fascism in some way. Thus, we have two main questions: when do they reach this point, and how should we connect them? In my interpretation, they should be connected to fascism when they neglect the individuality of persons; they use a national (ethnic) myth; and if they are authoritarians, they try to push political competitors and those who oppose them out of the society, thereby stepping out of the democratic realm, or try to reshape the political framework so that they can (nearly or completely) dominate.

If they stick to a more aggressive approach and use many fascist ideological patterns, we can call them neo-fascists. Thus, I interpret neo-fascism as a

Tilman Salomon, 'Zeev Sternhell: "Die Juden müssen sehr aufpassen”: Der israelische Politologe über die Entwicklung in Europa, die Gefahr eines neuen Faschismus und die Wahl Donald Trumps zum US-Präsidenten,' Jüdische Allgemeine, November 21, 2016, https://www.juedische-allgemeine.de/article/view/id/27074.

119 Eric Foner, The Story of American Freedom (London: Picador, 1998).

120 Michael Mann, 'Is Donald Trump a Fascist?' The Brooklyn Rail, May 1, 2017, https:// brooklynrail.org/2017/o5/field-notes/Is-Donald-Trump-a-Fascist. 
modernized, more aggressive version (a revival) of historical fascism. Please note that this understanding is slightly narrower than the interpretation used by several mainstream scholars, who use neo-fascism as a general term for streams showing some kind of continuity with fascism (see, for example, the works of Tamir Bar-On, Andrea Mammone or Nigel Copsey).

Moreover, if political forces reinterpret the fascist legacy, bring it closer to democratic rules, and either stay in the framework of democracy or only step out regarding certain points, we can call them post-fascists, where we observe that fascist-like, anti-Enlightenment elements dominate in their politics. I interpret post-fascism as an ideological framework which contains the core fascist, anti-Enlightenment ideas but does not radicalize these ideas to the level of proper fascism. Post-fascist groups are, in most cases, not as aggressive as the former. Roger Griffin wrote metaphorically about the post-fascism of AN: in his words, the party has set up camp on an island in a river: it does not reach the banks of fascism, but it does not belong to democracy either. ${ }^{121} \mathrm{I}$ slightly differ from this opinion. My view is that post-fascist forces are not like islands, but like boats: they move between proper fascism and conservatism, and they rest on both sides of the river. They use many of the emotional manipulations their historical predecessors did, from both sides, and we must call them post-fascists if we feel fascist elements are fundamental and extensive in their ideological framework. In this sense, I agree with Enzo Traverso, who in his book The New Faces of Fascism interprets the tenets of post-fascism in a very similar way to myself. As he puts it, 'the concept of postfascism emphasizes its chronological distinctiveness and locates it in a historical sequence implying both continuity and transformation. It certainly does not answer all the questions that have been opened up, but does emphasize the reality of change ... Fascism has not only been transnational or transatlantic, but also transhistorical.'122

When Alternative für Deutschland (AFD) in Germany attacks academics (i.e. the representatives of rationality) and asks students to report them to a website if they criticize the party, when US border agents do not help small children who cough blood for four days (thereby refusing to accept the human dignity of people), ${ }^{123}$ or when the EU revokes rescue ships from the Mediterranean sea,

Roger Griffin, 'The "Post-Fascism" of the Alleanza Nazionale: A Case Study in Ideological Morphology', Journal of Political Ideologies 1, no. 2 (1996): 143.

Traverso, The New Faces of Fascism, 4-5.

Ed Pilkington, 'Child Immigrant Detainees: "There's an Overwhelming Sadness Among Them"', The Guardian, May 12, 2015, https://www.theguardian.com/us-news/2015/may/12/ immigration-detention-centers-children. 
causing the death of thousands, these actions are all based on certain forms of the anti-Enlightenment value system, which does not respect universal human dignity, but only if he or she belongs to a certain ethnicity, nation or religion. This is a different question than locating the ideological border between post-fascism and other political streams (like conservatives with soft-xenophobic sentiments) which is a difficult job and opens the door to individual assessment. I would only call a political actor post-fascist if these elements in its politics are overwhelming. By 'conservatives' I mean political and social groups advocating traditional social institutions. Conservatives may implement many anti-Enlightenment ideas, but if the number and relevance of these elements is not extensive, these groups do not necessarily become post-fascists. The Christian Social Union (CSU) in Germany, for example, has made many xenophobic statements, but up to the point these are not met with more authoritarian measures, it would be a mistake to call the party post-fascist.

This also means, however, that scholars should reinterpret fundamental principles of fascism and the far right, as the ideology of most of the mainstream far right in the Western world, and especially the ideological framework of the radical right (or Alt-Right in the US), is post-fascism itself. The first major change in the anti-Enlightenment idea happened when it transformed itself into authoritarian regimes, and especially fascism, at the beginning of the twentieth century. Here, aggression and the nationalist myth were strengthened. The second step of this major transformation happened when, as Finchelstein argued, they reshaped their boundaries, tried to move closer to democracy, and created ideological systems these days called populism. This change toned down certain violent aspects of fascism. The first wave of anti-Enlightenment was represented by de Maistre, Burke and Herder; the second wave was represented by Gobineau, the Italian Fascists, Nazis and other authoritarians. The third wave came after the Second World War. This transformation made it possible to maintain a lighter version of identical ideas, and this is the reason why there are so many disputes about their fascistic nature. If we want to find important intellectuals, this third wave could be represented through the works of Evola, de Benoist or different far right politicians. The anti-Enlightenment idea is going through a major change in the twenty-first century, as we have reached the fourth wave: it is starting to lose its intellectual character, and a kind of 'trollization' has started, where anti-Enlightenment patterns are used without deeper intellectual aspirations, and its 'dadaized' version gets into mainstream politics in the form of vulgar xenophobia, racism and anti-pluralism. Also, a minority of the far right has started to implement clichés to conform with democratic principles in Europe: I consider this a change because of external forces (like 
social pressure), not necessarily an internal development, and I am very sceptical regarding the pacifying outcome of this phenomenon.

Copsey claims that 'the problem is that by bandying about the F-word, we end up with little more than a "booword", which is 'of little to no use when it comes to formulating precise categorizations. ${ }^{124}$ Even if this may be true, however, this 'booword' can be very important when pointing out similarities, and this is exactly what slowly disappeared from academic works on the far right in the last forty years. Creating newer and newer names for identical or similar phenomena instead of connecting such political streams to their roots and trying to answer the question of how to stop them was a mistake which apostrophized the language we use on post-fascism. Even if times change quickly, people, societies and their reflexes do not change as much as we presume. A perfect example of this desire to forget is the Polish ban on honest research into Polish peoples' participation and organization of pogroms. European societies tried to forget their past, and scholarship followed this approach. However, with the rise of so-called democratic populists forming autocracies, scholarship cannot follow the same principles as before. These regimes are the lighter forms of the former totalitarian ones. As the ideology was watered down in the second major change of the anti-Enlightenment idea, so the regimes these groups create are lighter than their historical predecessors, but they still do not conform to the democratic framework.

Moreover, it is especially vague to use the word 'populism' instead of 'post-fascism'. As Timothy Snyder put it in his book, The Road to Unfreedom:

Trump was called a 'populist'. A populist, however, is someone who proposes policies to increase opportunities for the masses, as opposed to the financial elites. Trump was something else: a sadopopulist, whose policies were designed to hurt the most vulnerable part of his own electorate. Encouraged by presidential racism, such people could understand their own pain as a sign of still greater pain inflicted upon others. The only major policy of 2017 was to increase pain: a tax regression law that created a budgetary argument against funding domestic programs, and which included among its provisions the deprivation of health care from many of those who needed it most. In Trump's words, 'I've ended the individual mandate' for health insurance. ${ }^{125}$ 
Deeper works also prove how the meaning of the word 'populism' was changed, which, in fact, was a kind of falsification of the terminology. ${ }^{126}$ Part of what is today called populism is a valid criticism of liberal democracies, and by calling post-fascism populism we hide the fact that the term 'populism' should be reserved for political streams which try to involve people in decision-making without extensive anti-Enlightenment elements. ${ }^{127}$

Based on the above, one can also ascertain that most of the extreme right groups belong to the neo-fascist camp, as they have reinterpreted the fascist tradition. Furthermore, it is a grave mistake not to notice the danger they represent, as the German Constitutional Court ruled in its NPD judgment. ${ }^{128}$ The difference between neo-fascism and post-fascism lies only in the way they radicalize the anti-Enlightenment idea, or the level of aggression with which they do so.

\section{Conclusion}

Sternhell's interpretation of fascism opened the door for future elaborative research on the causes of fascism and its successors. If we accept that Western culture still contains many anti-Enlightenment elements, what causes them to be present after more than two hundred years is a good question. Pointing out these elements can be very useful in understanding the structure of ideologies. It is no wonder that scholars talk about illiberal states; ${ }^{129}$ however, it is a mistake not to notice that this 'illiberalism' is rooted in a greater tradition. This could be interesting, as it causes the Western world great hardship to find

126 Anton Jäger, “The Myth of "Populism”,' Jacobin, March 1, 2018, https://www.jacobinmag. com/2018/o1/populism-douglas-hofstadter-donald-trump-democracy; Anton Jäger, 'The Semantic Drift: Images of Populism in Post-War American Historiography and their Relevance for (European) Political Science,' Constellations 24, no. 3 (2017), 310-323.

See Margaret Canovan, 'Taking Politics to the People: Populism as the Ideology of Democracy,' in Democracies and the Populist Challenge, ed. Yves Mény and Yves Surel (London: Palgrave Macmillan, 2002), 25-44.; Marco D'Eramo, 'Populism and the New Oligarchy,' New Left Review 82 (July-Aug 2013), 5-28; Rosanvallon, Counter-Democracy, 253-273. Ernesto Laclau, On Populist Reason (London, New York: Verso, 2005), 161-171.

'No prohibition of the National Democratic Party of Germany as there are no indications that it will succeed in achieving its anti-constitutional aims.' Press Release No. 4/2017 of January 17, 2017, https://www.bundesverfassungsgericht.de/SharedDocs/ Pressemitteilungen/EN/2017/bvg17-004.html. December 1997), 22-43; Fareed Zakaria, The Future of Freedom: Illiberal Democracy at Home and Abroad (New York: W. W. Norton \& Company, 2007). 
tools to protect itself from the rise of post-fascism. If such elements are present and are popular in a country or region on a wide scale, social constructivism is right insofar as they will probably be transformed into governmental systems, just as was done in the case of fascism, which also used many domestic intellectual clichés. Several different groups could promote such anti-Enlightened ideas, including conservatives, fundamentalist religious groups or the far left. If we trace the patterns and we put emphasis on countering them by teaching and explaining their flawed nature, there is a good chance that future generations will not follow the same rhetoric we have faced in European history for two centuries. If it is true that 'fascism is not only a political system, but also a cultural phenomenon, ${ }^{\prime}{ }^{130}$ we can only face it if we turn critically towards our own culture and put great emphasis on the teaching and explaining of values which belong to the Enlightenment tradition. This is especially true as the anti-Enlightenment 'comes to surface in times of crisis' and 'during times of general welfare it is not taken seriously'. ${ }^{131}$ From this perspective, it seems Francis Fukuyama is right when he provocatively writes in Foreign Affairs that to counterbalance the anti-Enlightenment tradition, Western cultures needed the realization some kind of a Leitkultur, 'a belief-system in equality and democratic values firmly grounded in the liberal ideals of the Enlightenment. ${ }^{132}$ If there is no such common ground for these societies, and there is no emphasis on defining and educating such values, the anti-Enlightenment tradition can get stronger and stronger, and if it gets the chance, it has the potential to transform or completely abolish a country's democratic framework.

This also means that Donald Trump, the Alt-Right, Nouvelle Droite, National Front or Viktor Orbán can be very different but they use very similar anti-Enlightenment intellectual panels, including xenophobia, authoritarianism, several nationalist clichés and, as Jason Stanley explained it, fascist-like political techniques. ${ }^{133}$ And, while such forces are probably unable to create proper fascist states, they can alter the common framework we build our societies on. This reshaping may have devastating consequences: it introduces the idea that humans are not equal; that some ethnic or political groups are superior to others and have the right to oppress lower ones; that not everybody deserves human rights; that political opponents can be banned, destroyed or even murdered; that elections can be manipulated

\footnotetext{
130 Salomon, 'Zeev Sternhell: “Die Juden müssen sehr aufpassen”.'

$131 \quad$ Ibid.

132 Francis Fukuyama, 'Against Identity Politics: The New Tribalism and the Crisis of Democracy,' Foreign Affairs, September/October 2018. Jason Stanley, How Fascism Works (New York: Random House, 2018).
} 
(because opinions do not count in the same way); that checks and balances are useless; that there are liberal enemies within and outside the state who want to destroy it; that nations are in a constant struggle against each other instead of in peace and cooperation; that weak nations and weak people (in vulnerable positions in our societies) deserve to disappear; and we could continue this list with many, many entries. To answer the question of what a future society would look like based on these anti-Enlightenment values: it would be a more peaceful but still horrible version of former fascist states. If the 'open minded' fascism Copsey mentioned can exist, ${ }^{134}$ then 'open minded', post-fascist autocracies can also exist. And I do not think any free person would want to live in such a country. 